\title{
Gut Micro-flora, Serum Bio-markers, and Growth Performance of Broiler Chickens Fed Supplemental Levels of Bacillus protease
}

\author{
*Chika E. Oyeagu, Victor Mlambo, Adaora S. Ezeuko and Francis B. Lewu.
}

\begin{abstract}
To maintain a high quality and low fibre content of broiler feeds may require an external influence, such as the Bacillus protease to overcome some of the potential limitations imposed by vegetable protein diets. There is paucity of information on serum biomarkers, and gut micro-flora composition of chickens fed dietary Bacillus protease. The objective was to test the effect of dietary Bacillus protease inclusion on gut micro-flora, serum bio-markers, and growth traits of chicken. A total of 300 - day - old "Cobb 500" chicks were randomly assigned to five dietary treatments with five replicates of 12 birds each. The treatments include; PROT0 (0 g/kg; control), PROT10 (1 g/kg), PROT15 (1.5 g/kg), PROT20 (2 g/kg) and PROT25 $(2.5 \mathrm{~g} / \mathrm{kg})$. The results showed that serum protein and albumin increased $(\mathrm{p}<0.05)$ while aspartate aminotransferase (AST) and alanine aminotransferase (ALT) decreased $(p<0.05)$, as the amount of Bacillus protease increased. Bacteria population did not differ ( $>0.05$ ). Daily feed intake and the feed intake at starter phase, finisher phase, and overall phase decreased $(\mathrm{p}<0.05)$ as the levels of protease increased. Birds fed PROT25 had the highest $(\mathrm{p}<0.05)$ weight gain and a better feed conversion ratio (FCR) throughout the feeding trial. It was concluded that $2.5 \mathrm{~g} / \mathrm{kg}$ Bacillus protease can be safely included for improved weight gain, FCR, carcass yield, retail cut yields and overall health status of chickens.
\end{abstract}

Keywords: Bacillus protease, broiler chicks, carcass yield, micro-flora.

\section{INTRODUCTION}

Poultry production is a significant component of the economy and supply of animal protein, which remains grossly insufficient in developing countries. Iyayi and Davis [1] suggested that the supply of poultry products in poorer countries could be effectively and rapidly expanded to meet the growing need for animal protein. This is technically feasible because poultry are

Manuscript received September 16, 2020. The authors wish to acknowledge the research office of Cape Peninsula University of Technology, Cape Town, South Africa for their financial support.

C. E. Oyeagu and F. B. Lewu are with the Department of Agriculture, Faculty of Applied Sciences, Cape Peninsula University of Technology, Wellington Campus, Private Bag X8, Wellington 7654, Cape Town, South Africa.

V. Mlambo is with Faculty of Agriculture and Natural Sciences, University of Mpumalanga, Private Bag X11283, Mbombela 1200, South Africa.

A. S. Ezeuko is with the Department of Pure and Industrial Chemistry, University of Fort Hare, Private Bag X1314, Alice 5700, South Africa. easily adaptable to most areas of the world, they have rapid gestation and development durations, with high muscle (flesh) tissue deposits. However, one of the biggest challenges to commercial poultry production is the availability of quality feeds at sustainable and stable prices. Kamel et al. [2] pointed out that protein is less digestible (80 - 85\%) than starch $(90 \%)$ in corn-soy diets, and that certain amounts of protein travel through the gastrointestinal tract without being completely digested [3]. Thus, the use of the mono-component protease enzyme may offer an opportunity to overcome some of the potential limitations imposed by vegetable - protein - based diets that may antagonize the serum biomarkers and growth of broiler birds [4]. Nutritional additives should be geared towards producing positive effects on the animal, promoting its health status and productive function while minimizing deleterious side - effects. Several serum enzymes are considered biomarkers that can be used to study liver and kidney functions. Elevated serum aspartate aminotransferase (AST) and alanine aminotransferase (ALT) concentrations indicate the release of aminotransferase from the cytoplasm to the blood stream, probably due to a damaged liver or differences in other tissues. Ahmad et al. [5] found that supplementations of protease had no adverse effect on the liver enzymes ALP, AST, and ALT and on total bilirubin concentrations. Xylanase and protease supplementation in broiler birds had no adverse effects on liver, kidney and various other internal organs [6]. Dietary multi-enzyme supplementation did not affect the serum alkaline phosphatase concentration of broiler birds [7]. The growth yield is closely linked to the nutrition quality of broilers, animals with an adequate supply and diversity of nutrients will promote the development of muscle tissues [8]. The addition of protease has been reported to improve the diet's protein digestibility and enhance nutrient availability for conversion of feed to meat yield [9], [10]. Exogenous protease supplementation can change the nutritional status and improve the growth of broiler chickens fed a corn-soybean meal diet [11]. Nutritional status is an important factor in the regulation of plasma hormones and intermediary metabolism in broiler birds [12], [13]. There is little information on serum biomarkers, and micro-flora composition of broiler birds fed dietary Bacillus protease. Therefore, this study sought to examine the effects of Bacillus protease supplementation on growth traits, gut micro-flora and serum biochemical profiles of broiler chickens fed maize-soybean meal diets. 


\section{MATERIALS AND METHODS}

\section{A. Ethical statement}

Ethical principles were taken into consideration during the study to adhere to the national and international standards governing research of this nature with regards to the use of research animals.

\section{B. Study site}

This study was conducted at the poultry unit of North-West University experimental farm (Molelwane), in the North-West province of South Africa. The study duration was six weeks.

\section{Enzyme characteristics}

The tested protease enzyme (RONOZYME ${ }^{\circledR}$ ProAct (RPA), DSM Nutritional Products Johannesburg South Africa) is a granulated heat-stable formulated product from Bacillus strain E A.l with an enzyme activity of $75,000 \mathrm{PROT} / \mathrm{g}$. One PROT is one protease unit, and is defined as the amount of enzyme that releases $1 \mathrm{mmol}$ of p-nitroaniline from $1 \mathrm{mM}$ substrate (Suc-Ala-Ala-Pro-Phe-pNA) per Adler minute at pH9.0 and $37^{\circ} \mathrm{C}$. The Bacillus enzyme was selected as feed enzyme candidate because of its bioactive intrinsic characteristics. According to the manufacturer, at peptic and acidic conditions $(\mathrm{pH})$, the enzyme retains more than $90 \%$ residual activity after $2 \mathrm{hrs}$ at $40^{\circ} \mathrm{C}(\mathrm{DSM})$.

\section{Experimental diets}

Iso-nitrogenous and iso-caloric experimental maize-soybean meal diets were used in this study. The feeding strategy consisted of starter $(0-21 \mathrm{~d})$ and finisher $(22-42 \mathrm{~d})$ basal diets (Tables 1 and 2), which were formulated to meet the birds' dietary nutrient requirements (NRC, 1994). At each feeding phase (i.e., starter and finisher) five dietary treatment were formulated by the addition of the Bacillus protease at five varying levels. The five experimental diets generated were Protease0, Protease 10, Protease15, Protease20 and Protease25 represented as PROT0 (only basal diet; BD), PROT10 (BD + 1 $\mathrm{g}$ protease $/ \mathrm{kg}$ diet), PROT15 (BD $+1.5 \mathrm{~g}$ protease $/ \mathrm{kg}$ diet $)$, PROT20 (BD $+2 \mathrm{~g}$ protease/kg diet) and PROT25 (BD $+2.5 \mathrm{~g}$ protease $/ \mathrm{kg}$ diet) respectively for both starter and finisher diets. The ingredient and chemical composition of the five experimental diets for the starter and finisher phases are presented in Tables 1 and 2, respectively. The chemical (proximate) composition of the experimental diets was analyzed according to AOAC (2006) methods with average crude protein and metabolizable energy of $23.70 \mathrm{CP}$ and $12.60 \mathrm{MJ}$ of ME/kg respectively for starter chicks while an average of $19.70 \mathrm{CP}$ and $13.00 \mathrm{MJ}$ of $\mathrm{ME} / \mathrm{kg}$ was recorded for finisher birds.
TABLE I. INGREDIENT (\%) AND CHEMICAL COMPOSITION (G/KG DM UNLESS OTHERWISE STATED) OF EXPERIMENTAL DIETS FOR BROILER CHICKS AT THE STARTER PHASE $(0-3$ WEEKS)

\begin{tabular}{|c|c|c|c|c|c|}
\hline Ingredient & PROT0 & PROT10 & PROT15 & PROT20 & PROT25 \\
\hline Yellow maize & 62.98 & 62.98 & 62.98 & 62.98 & 62.98 \\
\hline Soybean meal & 27.38 & 27.38 & 27.38 & 27.38 & 27.38 \\
\hline $\begin{array}{l}\text { Sunflower } \\
\text { meal }\end{array}$ & 4.00 & 4.00 & 4.00 & 4.00 & 4.00 \\
\hline Fish meal & 2.50 & 2.50 & 2.50 & 2.50 & 2.50 \\
\hline Canola oil & 0.11 & 0.11 & 0.11 & 0.11 & 0.11 \\
\hline Limestone & 1.32 & 1.32 & 1.32 & 1.32 & 1.32 \\
\hline MonoCaP & 0.44 & 0.44 & 0.44 & 0.44 & 0.44 \\
\hline Salt & 0.28 & 0.28 & 0.28 & 0.28 & 0.28 \\
\hline Methionine & 0.23 & 0.23 & 0.23 & 0.23 & 0.23 \\
\hline Threonine & 0.05 & 0.05 & 0.05 & 0.05 & 0.05 \\
\hline Lysine & 0.32 & 0.32 & 0.32 & 0.32 & 0.32 \\
\hline Choline $\mathrm{Cl}$ & 0.10 & 0.10 & 0.10 & 0.10 & 0.10 \\
\hline${ }^{1} \mathrm{VMP}$ & 0.20 & 0.20 & 0.20 & 0.20 & 0.20 \\
\hline${ }^{2}$ Maxiban & 0.05 & 0.05 & 0.05 & 0.05 & 0.05 \\
\hline${ }^{3}$ Surmax & 0.04 & 0.04 & 0.04 & 0.04 & 0.04 \\
\hline Protease & 0.00 & 0.10 & 0.15 & 0.20 & 0.25 \\
\hline Total & 100.00 & 100.00 & 100.00 & 100.00 & 100.00 \\
\hline \multicolumn{6}{|l|}{$\begin{array}{l}\text { Chemical } \\
\text { composition }\end{array}$} \\
\hline Moisture & 11.11 & 10.89 & 11.00 & 11.08 & 11.01 \\
\hline $\operatorname{ME}(\mathrm{kcal} / \mathrm{kg})$ & 2988.96 & 2984.86 & 2987.06 & 2982.99 & 2985.69 \\
\hline Crude protein & 23.83 & 23.90 & 23.79 & 23.85 & 23.88 \\
\hline Crude fat & 4.01 & 4.03 & 3.99 & 4.11 & 4.08 \\
\hline NDF & 15.32 & 15.27 & 15.39 & 15.28 & 15.30 \\
\hline ADF & 3.85 & 3.95 & 3.97 & 4.00 & 4.02 \\
\hline Calcium & 0.93 & 0.94 & 0.92 & 0.93 & 0.94 \\
\hline Phosphorus & 0.66 & 0.68 & 0.65 & 0.69 & 0.67 \\
\hline
\end{tabular}

MonoCaP $=$ Monocalcium Phosphate. Choline $\mathrm{Cl}=$ Choline Cloride. $\mathrm{VMP}=$ Vitamine mineral premix. $\mathrm{ME}=$ Metabolizable energy. $\mathrm{NDF}=$ Neutral detergent fibre. $\mathrm{ADF}=\mathrm{Acid}$ detergent fibre. PROT0 (only basal diet; BD), PROT10 (BD + $1 \mathrm{~g}$ protease), PROT15 (BD + $1.5 \mathrm{~g}$ protease), PROT20 (BD $+2 \mathrm{~g}$ protease) and PROT25 ( $\mathrm{BD}+2.5 \mathrm{~g}$ protease). ${ }^{1 \mathrm{la}} 2.5 \mathrm{~kg}$ of vitamin premix contained: $2700 \mathrm{mg}$ retinal, $400 \mathrm{mg}$ calcidiol, $18 \mathrm{~g}$ tocopheryl acetate, 2000 $\mathrm{mg}$ menadione, $1800 \mathrm{mg}$ thiamine, $6600 \mathrm{mg}$ riboflavin, $10 \mathrm{~g}$ niacin, $30 \mathrm{~g}$ calcium pantothenate, $3 \mathrm{~g}$ pyridoxine, $1 \mathrm{~g}$ folic acid, $15 \mathrm{mg}$ cobalamin, $250 \mathrm{~g}$ choline chloride, $100 \mathrm{mg}$ biotin. ${ }^{\mathrm{b}} 2.5 \mathrm{~kg}$ of trace mineral premix contained: $100 \mathrm{~g} \mathrm{Mn}, 50 \mathrm{~g} \mathrm{Fe}, 100 \mathrm{~g} \mathrm{Zn}, 10 \mathrm{~g} \mathrm{Cu}, 1 \mathrm{~g}$ I, $200 \mathrm{mg} \mathrm{Se} .{ }^{2} 1000 \mathrm{~g}$ of Maxiban contained: $80 \mathrm{~g} / \mathrm{kg}$ narasin, $80 \mathrm{~g} / \mathrm{kg}$ nicarbazin. ${ }^{~} 1000 \mathrm{~g}$ of Surmax contained: $100 \mathrm{~g} / \mathrm{kg}$ avilamycin

\section{E. Experimental birds and management}

A total of 300 one-day-old mixed-sexed broiler birds (Cobb $500^{\circledR}$ ) were used in this study. Sixty birds (five replication of 12 birds in each replicate per treatment group) were assigned randomly to one of the five experimental diets (PROT0, PROT10, PROT15, PROT20 or PROT25). Each experimental diet was replicated in five experimental pens with 12 birds per pen measuring $(2.5 \mathrm{~m}$ length $\times 2.5 \mathrm{~m}$ width $\times 2.5 \mathrm{~m}$ height $)$. The birds were housed in cages with wood shavings as litter and they were provided with feed and water ad libitum throughout the six-week feeding period. 
TABLE II. INGREDIENT (\%) AND CHEMICAL COMPOSITION (G/KG DM UNLESS OTHERWISE STATED) OF EXPERIMENTAL DIETS FOR BROILERS AT THE FINISHER PHASE (4 - 6 WEEKS).

\begin{tabular}{|c|c|c|c|c|c|}
\hline Ingredient & PROTO & PROT10 & PROT15 & PROT20 & PROT25 \\
\hline Yellow maize & 72.36 & 72.36 & 72.36 & 72.36 & 72.36 \\
\hline Soybean meal & 24.55 & 24.55 & 24.55 & 24.55 & 24.55 \\
\hline Canola oil & 0.24 & 0.24 & 0.24 & 0.24 & 0.24 \\
\hline Limestone & 1.25 & 1.25 & 1.25 & 1.25 & 1.25 \\
\hline MonoCaP & 0.17 & 0.17 & 0.17 & 0.17 & 0.17 \\
\hline Salt & 0.39 & 0.39 & 0.39 & 0.39 & 0.39 \\
\hline Methionine & 0.21 & 0.21 & 0.21 & 0.21 & 0.21 \\
\hline Tryptophan & 0.05 & 0.05 & 0.05 & 0.05 & 0.05 \\
\hline Threonine & 0.05 & 0.05 & 0.05 & 0.05 & 0.05 \\
\hline Lysine & 0.34 & 0.34 & 0.34 & 0.34 & 0.34 \\
\hline Choline Cl & 0.10 & 0.10 & 0.10 & 0.10 & 0.10 \\
\hline${ }^{1} \mathrm{VMP}$ & 0.20 & 0.20 & 0.20 & 0.20 & 0.20 \\
\hline${ }^{2}$ Maxiban & 0.05 & 0.05 & 0.05 & 0.05 & 0.05 \\
\hline${ }^{3}$ Surmax & 0.04 & 0.04 & 0.04 & 0.04 & 0.04 \\
\hline Protease & 0.00 & 0.10 & 0.15 & 0.20 & 0.25 \\
\hline Total & 100.00 & 100.00 & 100.00 & 100.00 & 100.00 \\
\hline \multicolumn{6}{|l|}{$\begin{array}{l}\text { Chemical } \\
\text { composition }\end{array}$} \\
\hline Moisture & 11.01 & 11.03 & 10.97 & 11.10 & 11.13 \\
\hline $\mathrm{ME}(\mathrm{kcal} / \mathrm{kg})$ & 3110.94 & 3115.76 & 3118.00 & 3111.85 & 3113.93 \\
\hline Crude protein & 19.75 & 19.91 & 19.70 & 19.83 & 19.85 \\
\hline Crude fat & 4.08 & 4.12 & 4.12 & 4.15 & 4.09 \\
\hline NDF & 15.93 & 18.32 & 18.28 & 18.21 & 18.02 \\
\hline $\mathrm{ADF}$ & 4.85 & 4.97 & 5.02 & 4.95 & 5.00 \\
\hline Calcium & 0.94 & 0.92 & 0.94 & 0.93 & 0.93 \\
\hline Phosphorus & 0.61 & 0.62 & 0.61 & 0.61 & 0.61 \\
\hline \multicolumn{6}{|c|}{$\begin{array}{l}\text { MonoCaP }=\text { Monocalcium Phosphate. Choline } \mathrm{Cl}=\text { Choline Cloride. VMP }=\text { Vitamine } \\
\text { mineral premix. ME }=\text { Metabolizable energy. NDF }=\text { Neutral detergent fibre. ADF }=\text { Acid } \\
\text { detergent fibre. PROT0 (only basal diet; } \mathrm{BD}), \text { PROT10 }(\mathrm{BD}+1 \mathrm{~g} \text { protease), PROT15 (BD + } \\
1.5 \mathrm{~g} \text { protease), PROT20 (BD }+2 \mathrm{~g} \text { protease) and PROT } 25\left(\mathrm{BD}+2.5 \mathrm{~g} \text { protease). }{ }^{1 \mathrm{a}} 2.5 \mathrm{~kg} \text { of }\right. \\
\text { vitamin premix contained: } 2700 \mathrm{mg} \text { retinal, } 400 \mathrm{mg} \text { calcidiol, } 18 \mathrm{~g} \text { tocopheryl acetate, } 2000 \\
\mathrm{mg} \text { menadione, } 1800 \mathrm{mg} \text { thiamine, } 6600 \mathrm{mg} \text { riboflavin, } 10 \mathrm{~g} \text { niacin, } 30 \mathrm{~g} \text { calcium } \\
\text { pantothenate, } 3 \mathrm{~g} \text { pyridoxine, } 1 \mathrm{~g} \text { folic acid, } 15 \mathrm{mg} \text { cobalamin, } 250 \mathrm{~g} \text { choline chloride, } 100 \mathrm{mg} \\
\text { biotin. } 2.5 \mathrm{~kg} \text { of trace mineral premix contained: } 100 \mathrm{~g} \mathrm{Mn}, 50 \mathrm{~g} \mathrm{Fe}, 100 \mathrm{~g} \mathrm{Zn}, 10 \mathrm{~g} \mathrm{Cu}, 1 \mathrm{~g} \\
\mathrm{I}, 200 \mathrm{mg} \text { Se. }{ }^{2} 1000 \mathrm{~g} \text { of Maxiban contained: } 80 \mathrm{~g} / \mathrm{kg} \text { narasin, } 80 \mathrm{~g} / \mathrm{kg} \text { nicarbazin. }{ }^{3} 1000 \mathrm{~g} \text { of } \\
\text { Surmax contained: } 100 \mathrm{~g} / \mathrm{kg} \text { avilamycin }\end{array}$} \\
\hline
\end{tabular}

\section{F. Serum biochemical profile}

At 42 days of age, five birds were randomly selected from each experimental pen, and $2 \mathrm{ml}$ of blood was collected from the wing vein using a sterile syringe and needles. The blood collected was transferred into a labelled treated vacutainer tubes. Red-top tubes without anticoagulant were used for serum biochemical analysis.

\section{G. Growth performance}

Average daily feed intake (ADFI) per bird was measured from day 1 to day 42 of age by subtracting the weight of the feed remaining from that of the feed initially supplied, and dividing the difference by the total number of birds in the pen. Average live-weight was measured weekly by weighing all the birds in each pen using a $10,100 \mathrm{~g}(10.1 \mathrm{~kg})$ capacity precision weighing balance with model, A and D Weighing GF-10K industrial balance, made in Japan. The feed conversion ratio (FCR) was calculated as follows: = Feed intake / weight gain, it is the mathematical relationship between the input of the feed that has been fed to the bird and the weight gain of the bird. FCR can provide a good indication of how efficient a feed or a feeding strategy can be.

\section{H. Cecal and ileum micro-flora composition}

Five birds per treatment at the age of 42 days were killed by severing the jugular vein. The abdominal cavity was opened, and the entire gastro intestinal tract was removed aseptically. All digesta contents of ileum, caecum and colon were collected immediately under aseptic conditions into sterile glass bags and put on ice before they were transported to the laboratory for enumeration of microbial populations.

\section{Statistical design and analysis}

Data collected during the study were subjected to analysis of variance (ANOVA) for Completely Randomized Design (CRD) [14] using General Linear Model Procedure [15]. The statistical model used to test the effects of treatment on meat quality traits, carcass characteristics, serum biochemical profiles, and gut micro-flora is presented as follows: $Y i j=\mu+P i+E i j$. Where: $Y i j=$ Observed value of a dependent variable; $\mu=$ Overall mean; $P i=$ Effect of different levels of dietary Bacillus protease enzyme; and $E i j=$ Residual error. The differences between means were tested for significance $(\mathrm{p}<0.05)$ using the LSD range test.

\section{RESULTS}

\section{A. Serum biochemical profile}

Serum biochemical parameters of broiler chickens fed maize-soybean meal diets with supplementary Bacillus protease are presented in Table 3. There were significant $(\mathrm{p}<0.05)$ differences between dietary treatments in terms of total protein, albumin, AST, and ALT, whereas urea, cholesterol, and alkaline phosphatase were not significantly $(\mathrm{p}>0.05)$ affected by diet. Total protein and albumin values increased $(\mathrm{p}<0.05)$ with increased levels of Bacillus protease supplementation. AST and ALT values decreased $(\mathrm{p}<0.05)$ as levels of Bacillus protease increased. Birds fed PROT0 or PROT10 had the highest $(\mathrm{p}<0.05)$ values of AST. Conversely, birds fed PROT15, PROT20, or PROT25 had the lowest ( $\mathrm{p}<0.05)$ AST values. The highest values of ALT was seen in birds fed PROT0, while birds in other treatments (PROT10, PROT15, PROT20, and PROT25) had significantly lower $(\mathrm{p}<0.05)$ ALT values.

TABLE III. THE EFFECT OF DIETARY PROTEASE SUPPLEMENTATION ON SERUM BIOCHEMICAL PARAMETERS OF BROILER BIRDS

\begin{tabular}{llllllll}
\hline Treatment & PROT0 & PROT10 & PROT15 & PROT20 & PROT25 & SEM & P-value \\
\hline Parameters & & & & & & & \\
Protein (g/L) & $27.50^{\mathrm{b}}$ & $29.20^{\mathrm{b}}$ & $33.20^{\mathrm{a}}$ & $32.80^{\mathrm{a}}$ & $30.80^{\mathrm{a}}$ & 0.43 & 0.04 \\
Albumin (g/L) & $11.50^{\mathrm{b}}$ & $11.50^{\mathrm{b}}$ & $13.10^{\mathrm{a}}$ & $12.90^{\mathrm{ab}}$ & $12.30^{\mathrm{ab}}$ & 0.12 & 0.02 \\
Urea (mmol/L) & 0.85 & 0.82 & 0.86 & 0.87 & 0.79 & 0.00 & 0.09 \\
Cholesterol & 2.84 & 2.88 & 3.10 & 3.11 & 2.89 & 0.01 & 0.10 \\
(mmol/L) & & & & & & & \\
ALP (IU/L) & 130.54 & 143.75 & 136.88 & 147.77 & 145.24 & 2.98 & 0.22 \\
AST (IU/L) & $331.18^{\mathrm{a}}$ & $320.30^{\mathrm{a}}$ & $278.22^{\mathrm{b}}$ & $269.30^{\mathrm{b}}$ & $265.85^{\mathrm{b}}$ & 6.87 & 0.03 \\
ALT (IU/L) & $15.33^{\mathrm{a}}$ & $12.63^{\mathrm{b}}$ & $12.57^{\mathrm{b}}$ & $12.99^{\mathrm{b}}$ & $11.59^{\mathrm{b}}$ & 0.13 & 0.01 \\
\hline
\end{tabular}

a,b,c,d; Row means with different superscripts differ significantly. SEM= Standard error of the mean. $\mathrm{AST}=$ Aspartate aminotransferase. $\mathrm{ALT}=$ alanine aminotransferase. $\mathrm{ALP}=$ alkaline phosphatase. PROT0 $=$ Basal Diet: $\mathrm{BD}$ (without PROT; protease). $\mathrm{PROT} 10=\mathrm{BD}+1 \mathrm{~g}$ PROT. $P R O T 15=\mathrm{BD}+1.5 \mathrm{~g}$ PROT. PROT20 $=\mathrm{BD}+2 \mathrm{~g}$ PROT. PROT $25=\mathrm{BD}+2.5 \mathrm{~g}$ PROT. 


\section{B. Gut micro-flora composition}

Table 4 shows the changes in caecum and ileum microbial population in birds fed corn-soybean meal diets with supplementary Bacillus protease. Although, different Bacillus protease levels used in the present study did not significantly ( $p>0.05$ ) influence the bacteria population in the ileum and caecum, however, there was a progressive increase in the numerical values reported for Lactobacillus and Bifidobacteria in both ileum and caecum as the levels of Bacillus protease increased. On the other hand, even though the E. coli counts was not influenced ( $p>0.05)$ by different levels of Bacillus protease, there was a progressive drop/decrease in the numerical values reported for E. coli as the inclusion levels of Bacillus protease increased.

TABLE IV. THE EFFECT OF DIETARY PROTEASE SUPPLEMENTATION ON BACTERIA COUNTS $\left(\log _{10} \mathrm{cfu} / \mathrm{g}\right)$ IN THE ILEUM AND CAECUM OF BROILERS FED CORN-SOYBEAN MEAL DIETS.

\begin{tabular}{llllllll}
\hline Treatment & $\begin{array}{l}\text { PRO } \\
\text { T0 }\end{array}$ & $\begin{array}{l}\text { PRO } \\
\text { T10 }\end{array}$ & $\begin{array}{l}\text { PRO } \\
\text { T15 }\end{array}$ & $\begin{array}{l}\text { PRO } \\
\text { T20 }\end{array}$ & $\begin{array}{l}\text { PRO } \\
\text { T25 }\end{array}$ & SEM & P-value \\
\hline Ileum & & & & & & & \\
Lactobacillus & 7.51 & 7.69 & 7.94 & 8.04 & 8.07 & 0.08 & 0.21 \\
Bifidobacteria & 5.19 & 5.30 & 5.49 & 5.64 & 5.67 & 0.03 & 0.17 \\
E. coli & 5.32 & 5.11 & 4.86 & 4.56 & 4.16 & 0.03 & 0.11 \\
Caecum & & & & & & & \\
Lactobacillus & 7.73 & 8.04 & 8.50 & 8.17 & 8.34 & 0.09 & 0.10 \\
Bifidobacteria & 6.97 & 7.07 & 7.11 & 7.53 & 7.59 & 0.06 & 0.09 \\
E. coli & 6.17 & 5.95 & 6.51 & 5.67 & 5.59 & 0.05 & 0.12 \\
\hline \multicolumn{2}{c}{ a,b,c,. Row means with different superscripts differ significantly. SEM= Standard error of the }
\end{tabular}
mean. E. coli $=$ Escharichia coli . PROT0 = Basal Diet: BD (without PROT; protease). PROT10 $=\mathrm{BD}+1 \mathrm{~g}$ PROT. PROT15 $=\mathrm{BD}+1.5 \mathrm{~g}$ PROT. PROT20 $=\mathrm{BD}+2 \mathrm{~g}$ PROT . PROT25 $=\mathrm{BD}+2.5 \mathrm{~g}$ PROT

\section{Growth performance}

The effects of dietary Bacillus protease supplementation on the growth performance of broiler chicks are shown in Table 5. The day - old weight of broilers did not differ significantly ( $>0.05)$ among the groups (i.e., treatments). Daily feed intake was highest $(\mathrm{p}<0.05)$ in birds fed PROT0 $(101.67 \mathrm{~g})$ and lowest $(\mathrm{P}<0.05)$ in birds fed PROT25 $(82.72 \mathrm{~g})$. Birds fed the highest amount of Bacillus protease (PROT25) recorded an improved $(\mathrm{p}<.0 .05)$ daily weight gain of $72.62 \mathrm{~g}$, while a daily weight gain of $64.35 \mathrm{~g}, 61.90 \mathrm{~g}, 60.87 \mathrm{~g}$ and $61.17 \mathrm{~g}$ were found for birds fed PROT0, PROT10, PROT15 and PROT20, respectively. During the starter phase, a lower $(\mathrm{p}<.0 .05)$ feed conversion ratio (FCR) value was observed in birds fed PROT25 relative to the other treatments (PROT0, PROT10, PROT15 or PROT20). Body weight gain was highest $(\mathrm{p}<.0 .05)$ for PROT25 fed birds yet birds fed PROT0, PROT10 or PROT20 consumed more feed $(p<.0 .05)$ than birds that received PROT25. At the finisher phase, the body weight gain of birds fed PROT25 was significantly higher $(p<.0 .05)$ than the gain of birds in the other treatment groups and similar with birds fed the control diet (PROT0). Birds fed PROT25 had the lowest ( $\mathrm{p}<.0 .05)$ FCR of 1.24 and an increased FCR of 1.75, 1.77, 1.76 and 1.76 was found in birds fed PROT0, PROT10, PROT15 or PROT20, respectively. Feed intake of birds fed the control diet (PROT0) was highest $(p<.0 .05)$, though similar to those that received PROT10 and PROT20, while PROT25 fed birds consumed less feed. The result showed that, the feed intake and FCR performance for birds during finisher phase maintained the same pattern of performance during the overall performance. As indicated in overall performance, birds fed PROT25 had a better ( $\mathrm{p}<.0 .05$ ) body weight gain of $3050 \mathrm{~g}$ than those that received other treatments $(2702.80 \mathrm{~g}, 2599.80 \mathrm{~g}, 2556.60 \mathrm{~g}$ and 2569.20g for PROT0, PROT10, PROT15 and PROT20, respectively).

TABLE V. THE EFFECT OF DIETARY PROTEASE SUPPLEMENTATION ON OVERALL FEED INTAKE, BODY WEIGHT GAIN AND FEED CONVERSION RATIO OF BROILER BIRDS

\begin{tabular}{|c|c|c|c|c|c|c|c|}
\hline Treatment & PROT0 & PROT10 & PROT15 & PROT20 & PROT25 & SEM & P-value \\
\hline \multicolumn{8}{|l|}{ Daily performance } \\
\hline Day old weight (g) & 44.00 & 45.00 & 45.00 & 44.00 & 45.00 & 0.12 & 0.22 \\
\hline Daily feed intake (g) & $101.67^{\mathrm{a}}$ & $95.94^{\mathrm{ab}}$ & $93.36^{\mathrm{b}}$ & $95.55^{\mathrm{ab}}$ & $82.72^{\mathrm{c}}$ & 0.65 & 0.02 \\
\hline Daily weight gain (g) & $64.35^{\mathrm{b}}$ & $61.90^{\mathrm{b}}$ & $60.87^{\mathrm{b}}$ & $61.17^{\mathrm{b}}$ & $72.62^{\mathrm{a}}$ & 0.15 & 0.04 \\
\hline \multicolumn{8}{|l|}{ Starter phase } \\
\hline Feed intake (g) & $1266.00^{\mathrm{a}}$ & $1211.00^{\mathrm{a}}$ & $1199.50^{\mathrm{ab}}$ & $1255.00^{\mathrm{a}}$ & $1087.80^{\mathrm{b}}$ & 1.75 & 0.04 \\
\hline Body weight gain (g) & $943.40^{\mathrm{b}}$ & $941.20^{\mathrm{b}}$ & $940.80^{\mathrm{b}}$ & $956.20^{\mathrm{b}}$ & $1065.00^{\mathrm{a}}$ & 1.69 & 0.02 \\
\hline FCR $(g / g)$ & $1.34^{\mathrm{a}}$ & $1.29^{\mathrm{a}}$ & $1.27^{\mathrm{a}}$ & $1.32^{\mathrm{a}}$ & $1.03^{\mathrm{b}}$ & 0.01 & 0.03 \\
\hline \multicolumn{8}{|l|}{ Finisher phase } \\
\hline Feed intake (g) & $3004.00^{\mathrm{a}}$ & $2817.80^{\mathrm{ab}}$ & $2721.30^{\mathrm{b}}$ & $2758.90^{\mathrm{ab}}$ & $2386.50^{\mathrm{c}}$ & 3.75 & 0.02 \\
\hline Body weight gain (g) & $1715.40^{\mathrm{ab}}$ & $1613.60^{\mathrm{b}}$ & $1570.80^{\mathrm{b}}$ & $1569.00^{\mathrm{b}}$ & $1940.00^{\mathrm{a}}$ & 1.98 & 0.04 \\
\hline $\mathrm{FCR}(\mathrm{g} / \mathrm{g})$ & $1.75^{\mathrm{a}}$ & $1.77^{\mathrm{a}}$ & $1.76^{\mathrm{a}}$ & $1.76^{\mathrm{a}}$ & $1.24^{\mathrm{b}}$ & 0.01 & 0.02 \\
\hline \multicolumn{8}{|l|}{ Overall performance } \\
\hline Feed intake $(\mathrm{g})$ & $4270.10^{\mathrm{a}}$ & $4029.40^{\mathrm{ab}}$ & $3920.80^{\mathrm{b}}$ & $4013.10^{\mathrm{ab}}$ & $3474.40^{c}$ & 4.46 & 0.02 \\
\hline Body weight gain (g) & $2702.80^{\mathrm{b}}$ & $2599.80^{\mathrm{b}}$ & $2556.60^{\mathrm{b}}$ & $2569.20^{\mathrm{b}}$ & $3050.00^{\mathrm{a}}$ & 3.33 & 0.04 \\
\hline FCR $(\mathrm{g} / \mathrm{g})$ & $1.79^{\mathrm{a}}$ & $1.59^{\mathrm{a}}$ & $1.57^{\mathrm{a}}$ & $1.59^{\mathrm{a}}$ & $1.16^{\mathrm{b}}$ & 0.01 & 0.01 \\
\hline
\end{tabular}

\section{DISCUSSION}

\section{A. Serum biochemical profile}

Proteases play an important role in blood bio-markers as they it influence blood clotting and improve the immune system [16], [17]. Serum total protein and albumin increased along with increased levels of Bacillus protease addition. Protein in the serum comprises albumin and globulin, these proteins serve many diverse functions, including transport of lipids, hormones, vitamins and minerals for proper functioning of the immune system [18], [19]. The results of the present study corroborate those of Abudabo [20] and Allouche et al. [21], which suggest that the addition of enzymes increases protein digestibility. According to Cowieson and Ravindran [22], the energy and amino acid profile of maize-based diets for broilers can be enhanced by the addition of protease, amylase, and xylanase. Nevertheless, elevations in serum albumin and total serum protein were found when the level of dietary supplementation with Bacillus protease increased, which may reflect the ability of this enzyme to make available sufficient protein from the ingested diets compared to birds that consumed control diet. Previous studies have showed an increase in the protein digestibility in birds fed a corn-soybean meal diet supplemented with Avizyme® 1500 (protease and xylanase) [20]. Birds fed PROT0 had an increased ALT and AST values, but birds fed 
PROT10 also recorded higher AST compared with birds fed higher levels of Bacillus protease (PROT15, PROT20 and PROT25). The presence of elevated ALT and AST levels are indicative of liver damage in broiler chicks, and thus comprises a valuable tool for determining a safe inclusion rate for feed additives, giving that diets may influence serum enzymes [23]. Some authors reported that elevated serum AST and ALT concentrations indicate the release of aminotransferase from cytoplasm to blood stream probably due to damage liver or different other tissues [5], [24]. This implies that birds fed diets without enzyme inclusion had adverse effect on hepatic cell and broiler health since higher concentration of AST and ALT indicates poor condition of some organs such as liver and kidney [18]. Enzyme supplementation significantly reduced the concentration of AST and ALT in chickens when compared to the control diet that had no enzyme. This findings is supported by those obtained by Lee et al. [25] and Mohamed et al. [23], who concluded that AST and ALT activities are indicative of liver and kidney damage in broiler chickens.

\section{B. Gut micro-flora composition}

In poultry, the micro-flora that colonizes the gastro-intestinal tract during the early post-hatch period forms a synergistic relationship with their host. Munyaka et al. [26] reported that the gut micro-flora performs an essential role in the nutrition and health of the host by encouraging digestion and absorption of nutrients, preventing pathogen's colonization, and shaping and keeping normal mucosal immunity. The major parameters for defining microbial structure and diversity are the richness and evenness of the bacteria. However, it is generally expected that dietary manipulations would influence the intestinal microbial structure and diversity [27]. According to Hubener $e t$ al. [28] and Masey et al. [29], the microbial population can be influenced by feed enzymes due to the changes imposed on the lumen contents. The non-significant differences recorded for bacteria populations in ileum and caecum are consistent with those of Gao et al. [13] who reported no significant change of Lactobacillus and Coliform bacteria counts in caecum content of 21-day-old birds. Luo et al. [6] did not find any effect of exogenous enzyme on counts of Escherichia coli, Lactobacillus and total aerobes in ileum and caecum of birds at $42 \mathrm{~d}$ of age. Similarly, Yang et al. [30] reported no significant differences in the small intestine micro-flora counts in broilers fed a range of feed additives. Although, different Bacillus enzyme levels used in the present study did not significantly influence the bacteria population in the ileum and caecum, but there was a progressive increase in the numerical values reported for Lactobacillus and Bifidobacteria in both ileum and caecum as the levels of Bacillus protease increased. On the other hand, even though the E. coli counts was not influenced by different levels of Bacillus protease, there was a progressive drop/decrease in the numerical values reported for E. coli as the levels of Bacillus protease increased. These observations may be due to the enzyme's ability to increase the levels of available substrate for microbial fermentation which improve protein digestibility and the production of short chain fatty acids (SCFA) in the gut as a result of non-digested protein diet that become available to the gut micro-biota [31]. Nabizadeh et al. [32] also reported a similar observation. It is possible that Bacillus protease supplementation resulted in the numerical multiplication of beneficial bacteria in the present study. According to Jozefiak et al. [33], exogenous enzyme acts not only by lowering intestinal viscosity, but it also leads to the development of more competitive bacterial communities with higher intra-bacterial competition, which limits bacterial interference with nutrient absorption, and may contribute to the potential reduction of pathogenic population. Dietary factors can also influence microbial populations in birds. Some authors [34] observed higher population of Escherichia coli and lactobacilli in the digesta of broilers that consumed wheat and barley, relative to those that received corn diets. Changes in the intestinal micro-biota of chickens can alter the mucosal structure and thereby influence nutrient absorptive capacity [26]. Many researchers reported that increasing SCFA density causes a gradual decrease in the proliferation rate of Enterobacteria but not that of Lactobacillus, Bifidobacteria [35], [36], [32]. Contrary to the results of this study, exogenous enzymes have been reported to modulate the gut micro-biota of birds which may in turn affect the health status and the extent of digestion by the host [37].

\section{Growth performance}

In the present study, the supplementation of Bacillus protease had an effect on body weight gain (BWG), feed intake (FI), and FCR of chicken at all phases of growth. Birds that received dietary treatment PROT25 had higher BWG and improved FCR with less FI. The optimum results may be obtained with $2.5 \mathrm{~g}$ of this enzyme (i.e., the highest level of Bacillus protease used the present study); the other treatments may have adversely affected variations in feeding and BWG patterns. This is similar to the broiler performance reported by Ghazi et al. [38] who attributed the performance to improved true metabolizable energy and true nitrogen digestibility. Dietary fiber was suggested to be responsible for accelerating digesta passage rate [39], [40]. However, due to the low fiber content of dietary PROT25 as a result of the maximum enzyme activities, broilers that received PROT25 may have experienced lower digesta passage rate than those fed other dietary treatments. Previous studies [41] reported that the longer the low fibre digesta in the intestinal tract, the greater the chances for better feed digestion which thereby improves growth performance. According to Engberg et al. [42] and Selle et al. [43], whole wheat (high fibre) feeding 
reduces the activities of amylase in the pancreatic tissue while the addition of protease increased chymotrypsin and lipase activities. The present results are also in line with the findings of Odetallah et al. [44] who reported that protease addition in a normal protein diet at 21 days of age resulted in a significant increase in BWG and decrease in feed intake. Similar results were reported by Odetallah et al. [45], who observed a significant increase in BWG and FCR in broilers supplemented with protease (versazyme) in high and normal protein diets. Kocher et al. [46] and Cowieson and Adeola [47] suggested that, improved BWG and FCR of birds fed dietary protease supplement may be attributed to the release of nutrients, making them available for utilization especially when feed ingredients are of low/inferior quality and/or with low bioavailability. Freitas et al. [48] noted a general decrease in FI of birds fed protease supplemented diets similar to the results obtained in the present study. The fact that chickens that received nutrient-dense diet fulfil their nutrient requirements by taking less amount of feed may explain why there was a decreased feed intake recorded for birds fed PROT25. This confirms the influence of protease in nutrients availability for chickens. Many authors share the same view [49], [50], [51]. Indeed, Hajati et al. [52] and Hajati [53] opined that enzyme supplementation might improve broiler performance by improving nutrient digestibility. This mechanism might be induced, at least partially, by a reduction of the viscosity due to decreased retention time of digesta in the gut [54]. Fru-Nji et al. [55] reported that protease supplementation, when included up to about $3 \%$ in broiler finisher, resulted in a non-significant improvement of BWG. Such incongruities may be due to differences in feed ingredient contents, levels of exogenous enzymes inclusion or breeds of chicken used [56].

\section{CONCLUSION}

We conclude that broiler chickens respond positively to supplementation with Bacillus protease with respect to gut micro-flora. Bacillus protease inclusion improved serum bio-markers, reducing AST and ALT activities that are indicative of liver and kidney damage in broiler chickens. In other words, the Bacillus protease protects the liver and kidney, which thereby stabilized the health status of the chickens. Summarily, birds fed $2.5 \mathrm{~g} / \mathrm{kg}$ feed (PROT25) produced a better FCR and higher weight gain.

\section{ACKNOWLEDGMENT}

The authors wish to acknowledge Late Prof Voster Muchenje for his financial support. Many thanks to the Department of Animal Science, North-West University, Mafikeng Campus, South Africa for providing facilities for this research trial. Again, the authors wish to acknowledge Cape Peninsula
University of Technology, Cape Town, South Africa for their financial support.

\section{REFERENCES}

[1] Iyayi Eustace and Bina I. Davies, (2005). Effect of Enzyme Supplementation of Palm Kernel Meal and Brewer`s Dried Grain on the Performance of Broilers. International Journal of Poultry Science 4(2):76-80. DOI:10.3923/ijps.2005.76.80. Source: https://scialert.net>abstract>doi=ijps.2005.76.80.

[2] N. F. Kamel, Naela M. Ragaa, R.A. El-Banna and F.F. Mohameda, (2015). Effects of a Monocomponent Protease on Performance Parameters and Protein Digestibility in Broiler Chickens. Agriculture and Agricultural Sci Procedia. 6: 216-225. Doi:10.1016/j.aaspro.2015.08.062.Source:https://www.sciencedirect.co $\mathrm{m} /$ journal/agriculture-and-agricultural-science-procedia/vol/6/suppl/C

[3] A. Lemme, V. Ravindran and W.L. Bryden, (2004). Ileal digestibility of amino acids in feed ingredients for broilers. World's Poult Sci J. 60:423-437.Doi:10.1079/WPS200426.Source:https://www.cambridge.or g/core/journals/world-s-poultry-science-journal/volume/DF76412BC1D BD37BAC6365143330FC6F

[4] T. S. Mushtag, M. Ahmad, G. Mirza, M.A. Ahmad and T. Noreen, (2009). Influence of sunflower meal based diet supplemented with exogenous enzyme and digestible lysine on performance, digestibility and carcass response of broiler chickens. Anim Feed Sci Technol. 149; 275-286. Doi: 10.1016/j.anifeedsci.2008.06.008.Source:https://www.sciencedirect.co $\mathrm{m} /$ journal/animal-feed-science-and-technology/vol/149/issue/3

[5] Ahmad Zulfiqar, Masood Sadiq Butt, Riaz Hussain, Anwaar Ahmed and Muhammad Riaz, (2013). Effect of Oral Application of Xylanase on Some Hematological and Serum Biochemical Parameters in Broilers. Pak Vet J. 33: 388-390. Available from: http://www.pvj.com.pk/archive/Volume_33_Issue_3_2013.htm

[6] D. Luo, F. Yang, X. Yang, J. Yao, B. Shi and Z. Zhou, (2009). Effects of xylanase on performance, blood parameters, intestinal morphology, microflora and digestive enzyme activities of broilers fed wheat-based diets. Asian-Aust $J$ Anim Sci. 22: 1288-1295. Doi: https://doi.org/10.5713/ajas.2009.90052.Source:https://www.ajas.info/c urrent/index.php?vol=22\&no $=9 \&$ special $=$

[7] D. Medhi, H.F. Ahmed, B.K. Konwar, and P. Chakravarty, (2003). Effect of dietary ajar seed meal with or without multienzyme supplementation on voluntary feed intake and nutrients digestibility in broilers. Indian Vet J. 80: 667-671.Available from: https://ivj.org.in/users/members/viewarticles.aspx?Y=2003\&I=767

[8] F. S. Dalólio, D.P. Vaz, J. Moreira, L.F.T. Albino and L.R. Valadares, (2015). Carcass characteristics of broilers fed enzyme complex. Biotechnol Anim Husb. 31: 153-162. Doi: 10.2298/BAH1502153D. Source: http://www.journals4free.com/link.jsp?l=13442975

[9] C. Wenk, (2000). Recent advances in animal feed additives such as metabolic modifiers, antimicrobial agents, probiotics, enzymes and highly available minerals - Review. Asian-Australian J Anim Sci. 13: 86-95. Doi: https://doi.org/10.5713/ajas.2000.86 Source: https://www.ajas.info/current/index.php?vol=13\&no=1\&special=

[10] H. I. Ajayi, (2015). Effect of protease supplementation on performance and carcass weights of broiler chickens fed low protein diets. Nig J Agric Food Env. 11: 29-32. Available from:http://njafe.com/njafe2015Vol11number1.html

[11] Buyse, J., K. Jassens, S. van der Geyten, P. van As, E. Decuypere and V.M. Darras, 2002. Pre-and postprandial changes in plasma hormone and metabolite levels and hepatic deiodinase activities in meal-fed broiler chickens. Br J Nutr. 88: 641-653. DOI: 10.1079/BJN2002741. Source: https://www.cambridge.org/core/journals/british-journal-of-nutrition/iss ue/386964FB6C0C6EC1598792B287E5A3A8

[12] Q. Swennen, G.P.J. Janssens, S. Millet, G. Vansant, E. Decuypere, and J. Buyse, (2005). Effects of substitution between fat and protein on food intake and its regulatory mechanisms in broiler chickens: Endocrine functioning and intermediary metabolism. Poult Sci. 84: 1051-1057. Doi:10.1093/ps/84.7.1051.Source:https://academic.oup.com/ps/article/8 4/7/1051/1553210

[13] F. Gao, Y. Jiang, G.H. Zhou and Z.K. Han, (2008). The effects of xylanase supplementation on performance, characteristics of the gastrointestinal tract, blood parameters and gut microflora in broilers fed 
on wheat-based diets. Anim Feed Sci Technol. 142: 173-184.Doi: 10.1016/j.anifeedsci.2007.07.008.

Source: https://www.sciencedirect.com/journal/animal-feed-science-and-technol ogy/vol/142/issue/1

[14] R. G. D. Steel, and J.H. Torrie, (1980). Principles and procedures of statistics. A biometric approach.2nd ed. New York (NY): McGraw-Hill Publishers. 1980. Source: https://trove.nla.gov.au/work/9171434

[15] SAS. (2010). SAS Users Guide: Statistics, Version 9.3 SAS Institute, Cary, NC, USA. Source: https://www.amazon.com/SAS-STAT-9-3-Users-Guide/dp/1607649217

[16] N. M. Hooper, (2002). Proteases in biology and medicine. London: Portland Press. ISBN 1-85578-147-6. Source: https://onlinelibrary.wiley.com/doi/10.1002/cbf.1060

[17] X. S. Puente, and C. López-Otín, (2004). "A genomic analysis of rat proteases and protease inhibitors". Genome Res. 14: 609-622. Doi: 10.1101/gr.1946304. Source: https://genome.cshlp.org/content/14/4.toc

[18] Adkins Joshua, N., Susan M. Varnum, Kenneth J. Auberry, Ronald J. Moore, Nicolas H. Angell, Richard D. Smith, David L. Springer and Joel G. Pounds, (2002). "Toward a human blood serum proteome: analysis by multidimensional separation coupled with mass spectrometry". Molec. and Cellul. Proteomics. 1: 947-955. Doi: 10.1074/mcp.M200066-MCP200. Source: https://www.mcponline.org/content/1/12

[19] P. E. Geyer, N.A. Kulak, G. Pichler, L.M. Holdt, D. Teupser and M. Mann, (2016). "Plasma Proteome Profiling to Assess Human Health and Disease". Cell Syst. 2: 185-95. Doi: 10.1016/j.cels.2016.02.015.Source: https://www.sciencedirect.com/journal/cell-systems/vol/2/issue/3

[20] A. Abudabo, (2010). Enzyme supplementation of corn-soybean meal diets improves performance in broiler chicken. Int. J. Poult. Sci. 9: 292-297. Doi: 10.3923/ijps.2010.292.297.Source: https://scialert.net/archivedetails.php?issn $=1682$-8356\&issueno $=148$

[21] L. Allouche, T. Madani, Z. Ait Hamouda, M.R. Boucherit, H. Taleb, O. Samah, K. Rahmani and A. Touabti, (2015). Effect of addition of exogenous enzymes in hypocaloric diet in broiler chicken on performance, biochemical parameters and meat characteristics. Biotech. in Ani. Husb. 31: 551-565. Doi: 10.2298/BAH1504551A.Source: http://www.journals4free.com/link.jsp?l=13442975

[22] A. J. Cowieson, and V. Ravindran, (2008). Effect of exogenous enzymes in maize-based diets varying in nutrient density for young broilers: growth performance and digestibility of energy, minerals and amino acids. Brit. Poult. Sci. 49: 37-44. Doi: 10.1080/00071660701812989. Source: https://www.tandfonline.com/toc/cbps20/49/1?nav=tocList

[23] I. Mohamed, El-Katcha Mosaad, A. Soltan Hany, F. El-Kaney and El-Sayed R. Karwarie, (2014). Growth Performance, Blood Parameters, Immune response and Carcass Traits of Broiler Chicks Fed on Graded Levels of Wheat Instead of Corn Without or With Enzyme Supplementation. Alexandria J. Vet. Sci. 40: 95-111. Doi: 10.5455/ajvs.48232.Source: https://www.alexjvs.com/

[24] N. Abida, K. Amber, A. Zunaira, A. Anam, I. Bushra, K. Shaneel, R. Laiba, A. Ramsha and N. Faiza (2017). Effect of supplementation of xylanase on feed efficiency and serum biochemistry in broilers. Res. J. Pharmacol Pharmac. 1:1-9. Available from: http://escipub.com/research-journal-of-pharmacology-and-pharmacy/

[25] S. Y. Lee, J.S. Kim, J.M. Kim, B.A. An and C.V Kang, (2010). Effects of multiple enzyme (ROVABIO[R] Max) containing carbohydrolases and phytase on growth performance and intestinal viscosity in broiler chicks fed corn-wheat-soybean meal based diets. Asian-Australasian J. Anim. Sci. 23: 1198-1204. Doi: 10.5713/ajas.2010.90592.Source: https://www.ajas.info/current/index.php?vol=23\&no=9\&special=

[26] P. M. Munyaka, N.K. Nandha, E. Kiarie, C.M. Nyachoti and E. Khafipour, 2016. Impact of combined $\beta$-glucanase and xylanase enzymes on growth performance, nutrients utilization and gut microbiota in broiler chickens fed corn or wheat-based diets. Poult. Sci. 95: 528-540. Doi: 10.3382/ps/pev333. Source: https://academic.oup.com/ps/issue/95/3

[27] E. Kiarie, L.F. Romero and V. Ravindran, (2014). Growth performance, nutrient utilization, and digesta characteristics in broiler chickens fed corn or wheat diets without or with supplemental xylanase. Poult Sci. 93: 1186-1196. Doi: 10.3382/ps.2013-03715.Source: https://academic.oup.com/ps/issue/93/5?browseBy=volume

[28] K. Hubner, W. Vahjen and O. Simon, 2002. Bacterial responses to different dietary cereal type and xylanase supplementation in the intestine of broiler chicken. Archivos Anim Nutr. 56: 167-187. Doi: 10.1080/00039420214191.Source:https://www.tandfonline.com/toc/gaa n19/56/3?nav=tocList

[29] H. V. Masey O’Neill, J. A. Smith and M. R Bedford, (2014). Multicarbohydrase enzymes for non-ruminants. Asian Australas $J$ Anim Sci. 27: 290-301. Doi: 10.5713/ajas.2013.13261. Source: https://www.ajas.info/current/index.php?vol=27\&no=2\&special $=$

[30] Y. Yang, P. A. Iji, A. Kocher, L. L. Mikkelsen and M. Choct, (2007). Effects of Mannan oligosaccharide on growth performance, the development of gut microflora, and gut function of broiler chickens raised on new litter. J Appl Poult Res. 16: 280-288. Doi: 10.1093/japr/16.2.280. Source: https://academic.oup.com/japr/issue/16/2

[31] J. Morrison Douglas, and Tom Preston, (2016). Formation of short chain fatty acids by the gut microbiota and their impact on human metabolism. Gut Microbes 7: 189-200.Doi: 10.1080/19490976.2015.1134082.Source: https://www.tandfonline.com/toc/kgmi20/7/3?nav=tocList

[32] A. Nabizadeh, A. Golian, A. Hassanabadi and S. Zerehdaran, (2017). Effects of Nutrient Density and exogenous enzymesin Starter Diet on Performance, Intestinal Microflora, Gut Morphology and Immune Response of Broiler Chickens. Braz J Poult Sci. 19: 509-518.Doi: 10.1590/1806-9061-2017-0501.Source:http://www.scielo.br/scielo.php? script $=$ sci_issuetoc\&pid $=1516-635 \times 20170003 \& \operatorname{lng}=$ en\&nrm $=$ iso

[33] D. Jozefiak, A. Rutkowski, S. Kaczmarek, B.B. Jensen, R.M. Engberg and O. Hojbjerg, (2010). Effect of $\beta$-glucanase and xylanase supplementation of barley- and rye-based diets on caecal microbiota of broiler chickens. British Poult Sci. 51: 546-557.Doi: 10.1080/00071668.2010.507243.Source: https://www.tandfonline.com/toc/cbps20/51/4?nav=tocList

[34] M. L. Rodriguez, A. Rebol'e, S. Velasco, L. T. Ortiz, J. Trevino and C. Alzueta, (2012). Wheat- and barley-based diets with or without additives influence broiler chicken performance, nutrient digestibility and intestinal micro-flora. J. Sci. Food Agric. 92: 184-190. Doi: 10.1002/jsfa.4561.Source:https://onlinelibrary.wiley.com/toc/10970010/ 2012/92/1

[35] P. W. Van-der Wielen, S. Biesterveld, S. Notermans, H. Hofstra, B.A.P. Urlings and F. van Knapen, (2000). Role of volatile fatty acids in development of the cecal microflora in broiler chickens during growth. $J$ Appl Env Microbiol. 66: 2536-2540.

[36] D. Józefiak, A. Rutkowski and S. A. Martin, (2004). Carbohydrate fermentation in the avian ceca - A review. Anim Feed Sci Tech. 113: $1-15$. Doi: 10.1016/j.anifeedsci.2003.09.007.Source:https://www.sciencedirect.co $\mathrm{m} /$ journal/animal-feed-science-and-technology/vol/113/issue/1

[37] M. R. Bedford, and A. J. Cowieson, (2012). Exogenous enzymes and their effects on intestinal microbiology. Anim Feed Sci Technol. 173: 76-85.Doi:10.1016/j.anifeedsci.2011.12.018.Source:https://www.scienc edirect.com/journal/animal-feed-science-and-technology/vol/173/issue/1

[38] S. Ghazi, J. A. Rooke, H. Galbraith and M. R. Bedford, (2002). The potential for the improvement of the nutritive value of soya-bean meal by different proteases in broiler chicks and broiler cockerels. British Poult Sci. 43: 70-77. Doi: 10.1080/00071660120109935.Source: https://www.tandfonline.com/toc/cbps20/43/1?nav=tocList

[39] A. Wilfarta, L. Montagne, H. Simmins, J. Noblet and H. van Milgen, (2007). Digesta transit in different segments of the gastrointestinal tract of pigs as affected by insoluble fibre supplied by wheat bran. British $\mathbf{J}$ Nutr. 98: 54-62. Doi: 10.1017/S0007114507682981.Source:https://www.cambridge.org/core/j ournals/british-journal-of-nutrition/issue/12FD9F134BBC960A84FB73 0D1D6BD222

[40] P. Sayehban, A. Seidavi, M. Dadashbeiki, A. Ghorbani, W. A. G. Araújo and L. F. T. Albino, (2015). Effects of Different Dietary Levels of Two Types of Olive Pulp and Exogenous Enzyme Supplementation on the Gastro-intestinal tract size, Immunology and Hematology of Broilers. Brazilian J. Poult. Sci. 17: Special Issue. 73 - 85.Doi: 10.1590/1516-635XSPECIALISSUENutrition-PoultryFeedingAdditives 073-086.Source:http://www.scielo.br/scielo.php?script=sci_issuetoc\&pi $\mathrm{d}=1516-635 \mathrm{X} 20150010 \& \operatorname{lng}=$ en\&nrm $=$ iso

[41] P. Sayehban, A. Seidavi, M. Dadashbeiki, A. Ghorbani, W. A. G. Araújo and L. F. T. Albino, (2016). Effects of Different Levels of Two Types of Olive Pulp with or without Exogenous Enzyme Supplementation on Broiler Performance and Economic Parameters. Brazilian J Poult. Sci. 
18: 489-499. Doi: 10.1590/1806-9061-2015-0060.Source:http://www.scielo.br/scielo.php? script=sci_issuetoc\&pid=1516-635X20160003\&lng=en\&nrm=iso

[42] R. M. Engberg, M. S. Hedemann, S. Steenfeldt and B. B. Jensen, (2005). Influence of whole wheat and xylanase on broiler performance and microbial composition and activity in the digestive tract. Poult Sci. 83: 925-938. Doi: 10.1093/ps/83.6.925.Source: https://academic.oup.com/ps/issue/83/6?browseBy=volume

[43] P. H. Selle, D. J. Cadogan, Y. J. Ru and G. G. Partridge, (2010). Impact of exogenous enzymes in Sorghum or wheat based broiler diets on nutrient utilization and growth performance. Int. J. Poult. Sci. 9: 53-58. Doi: 10.3923/ijps.2010.53.58.Source: https://scialert.net/archivedetails.php?issn=1682-8356\&issueno=146

[44] N. H. Odetallah, J. J. Wang, J. D. Garlich and J. C. Shih, (2003). Keratinase in Starter diets improves growth of broiler chicks. Poult Sci. 82: 664-670. Doi: 10.1093/ps/82.4.664.Source: https://academic.oup.com/ps/issue/82/4?browseBy=volume

[45] N. H. Odetallah, J. J. Wang, J. G. Garlich and J. C. Shih, (2005). Versazyme supplementation of broiler diets improves market growth performance, Poult Sci. 84: 858-64.Doi: 10.1093/ps/84.6.858.Source: https://academic.oup.com/ps/issue/84/6?browseBy=volume

[46] A. Kocher, M. Choct, M. D. Porter and J. Broz, (2002). Effects of feed enzymes on nutritive value of soyabean meal fed to broilers. Bri. Poult. Sci. 43: 54-63. Doi: 10.1080/00071660120109890.Source:https://www.tandfonline.com/toc/ cbps20/43/1?nav=tocList

[47] A. J. Cowieson, and O. Adeola, (2008). Carbohydrases, Protease, and Phytase Have an Additive Beneficial Effect in Nutritionally Marginal Diets for Broiler Chicks. Poult Sci. 87: 1860-1867. Doi: 10.1093/ps/84.12.1860.Source:https://academic.oup.com/ps/issue/84/12 ?browseBy=volume

[48] D. M. Freitas, S. L. Vieira, C. R. Angel, A. Favero and A. Maiorka, (2011). Performance and nutrient utilization of broilers fed diets Supplemented with a novel mono component protease. J. Appl. Poult. Res. 20: 347-352. Doi: 10.3382/japr.2010-00295.Source: https://academic.oup.com/japr/issue/20/3?browseBy=volume

[49] M. J. Alam, M. A. R. Howlider, M. A. H. Pramanik and M. A. Haque, 2003. Effect of Exogenous Enzyme in Diet on Broiler Performance. Int. J. Poult. Sci. 2: 168-173. Doi: 10.3923/ijps.2003.168.173.Source: https://scialert.net/archivedetails.php?issn=1682-8356\&issueno=67

[50] C. E. Oyeagu, A. O. Ani, C. F. Egbu, F. U. Udeh, J. N. Omumuabuike and J. C. Iwuchukwu, (2016). The effect of Feeding Toasted Bambara nut (Vignasubterranea (L) verdc) offal and Supplementary Enzyme on Performance of Broiler Chicks. Journal of Tropical Agriculture (Trinidad) 93: 271-283.Available from: https://journals.sta.uwi.edu/ta/index.asp?action=viewIssue\&issueId=127

[51] C. E. Oyeagu, V. Mlambo and V. Muchenje, (2019). Effect of dietary Aspergillus xylanase on nutrient digestibility and utilization, growth performance and size of internal organs in broiler chickens offered maize-soybean meal based-diets. Pakistan $J$ Nutr. 18: 852-865. Doi: 10.3923/pjn.2019.852.865.Source:https://scialert.net/archivedetails.php ?issn $=1680-5194 \&$ issueno $=172$

[52] H. Hajati, M. Rezaei and H. Sayyahzadeh, (2009). The Effects of Enzyme Supplementation on Performance, Carcass Characteristics and Some Blood Parameters of Broilers Fed on Corn-Soybean Meal-Wheat Diets. Int. J. Poult. Sci. 8: 1199-1205. Doi: 10.3923/ijps.2009.1199.1205.Source:https://scialert.net/archivedetails.p hp?issn $=1682-8356$ \&issueno $=145$

[53] H. Hajati, (2010). Effects of Enzyme Supplementation on Performance, Carcass characteristics, Carcass Composition and Some Blood Parameters of Broiler Chicken. American J. Anim. Vet. Sci. 5: 221-227. Doi: https://thescipub.com/issue-ajavs $/ 5 / 3$ 10.3844/ajavsp.2010.221.227.Source:

[54] C. E. Oyeagu, A. O. Ani, C. F. Egbu, E. S. Akpolu, J. C. Iwuchukwu and J. N. Omumuabuike, (2015). Performance of broiler finisher birds fed Toasted Bambara nut (Vigna subterranean (L) verdc) Offal with supplementary enzyme. Asian J. Sci. Technol. 6: 934-939.Available from: https://www.journalajst.com/archive/201501?page=1

[55] F. Fru-Nji, A. M. Kluenter, M. Fischer and K. Pontoppidan, (2011). A feed serine protease improves broiler Performance and energy digestibility. J. Poult. Sci. 48: 239-246. Doi: 10.2141/jpsa.011035. Source: https://www.jstage.jst.go.jp/browse/jpsa/48/4/ contents/-char/en

[56] C. R. Angel, W. Saylor, S. L. Vieira and N. Ward, (2011). Effects of a monocomponent protease on performance and protein utilization in 7- to 22-day-old broiler chickens. Poult. Sci. 90: 2281-2286. Doi: 10.3382/ps.2011-01482.Source:https://academic.oup.com/ps/issue/90/1 0 ?browseBy=volume

\section{Author Biography}

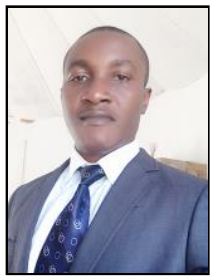

Chika E. Oyeagu hails from the Eastern part of Nigeria, precisely, Enugu State. After attending primary and secondary education, he gained admission in Animal Science Department, University of Nigeria Nsukka, Nigeria in 2003. He graduated with B. Agric (Animal Science) in the year 2008. He enrolled for his Master's degree in the University of Nigeria Nsukka, Nigeria, in 2012, and graduated in 2014 with his specialty in Animal Biochemistry and Nutrition. He later gained admission for his $\mathrm{PhD}$ in the Department of Livestock and Pasture Sciences, University of Fort Hare, Alice, South Africa, in 2015, and graduated in 2019.

Chika worked at Folad Farms LTD in Edo State Nigeria as farm manager in 2009 - 2011. During his PhD studies (2016 - 2019), he served as a research assistance and he taught different Undergraduate and Honours modules. He is currently a Post-Doctoral Research Fellow in the Department of Agriculture, Cape Peninsula University of Technology, Wellington Campus, Cape Town South Africa. In the year 2019, Chika published 6 (six) papers in different DHET accredited journals. In 2020, three paper has been accepted in different DHET accredited journals, while three others has been accepted in DHET accredited conference proceedings. However, a number of manuscripts are still under review in different journals. Chika has a strong background in Agriculture, meat science, livestock nutrition, health and production.

Dr. Oyeagu received NRF financial award in the first year of his $\mathrm{PhD}$, and he also received the institutional financial award subsequently. 